\title{
Village Government Capacity in Village Fund Budget Management in Pulau Sembilan District, Sinjai Regency
}

\author{
Muhammad Takdir, Andi Bahrun Syam², Sakrawandi ${ }^{3}$ \\ 1,2,3 Universitas Muhammadiyah Sinjai \\ Email: takdirstisip@gmail.com
}

\begin{abstract}
Rural development is a priority agenda for national development to improve the welfare of the people. The results of this study examine how the ability of the village government to utilize the village fund budget is so large, without any form of deviation. In public sector studies, capacity is defined as the ability to manage human resources, finance, physical infrastructure, and information. In this study, qualitative research methods were used to obtain accurate data and collect reliable data from related institutions and informants. The informants in the study were 7 village heads. The findings in this study are that the capacity of the village government in managing the village funds budget in Pulau Sembilan District, Sinjai Regency is not optimal
\end{abstract}

Keywords: Capacity, Government, Village

\section{INTRODUCTION}

The government believes that to build the country, it must first strengthen and build villages (Prasodjo, 2017; Rakib \& Syam, 2016; Wijaya \& Sari, 2020), building Indonesia from the periphery by strengthening rural areas within the framework of the unitary state of the Republic of Indonesia, the government places a fairly dominant priority through the policy of allocating village development budgets that comes from the state budget by the mandate of the Village Law (Eko et al., 2014).

Data on the use of village funds as released by the Anti Corruption Committee (ACC) data on corruption case handling based on the transfer of cases from the prosecutor's office to the district court, one of the most highlighted cases is the misuse of village funds as many as 22 cases as of 13 December 2018. irregularities in the misuse of the village fund budget because previously the village government had never managed large amounts of money (Ibrahim, 2019; Sulila, 2020; Zulkifli et al., 2018), suddenly asked to manage billions of money into a breath of fresh air that can manage it by the mandate of the law, but on the other hand, for village governments that cannot be responsible, the occurrence of corruption in village funds is possible does not mean taking state money intentionally but it could be due to careless use or administrative errors in accountability resulting in a finding of budget misuse (Mauro, 1998; Persson et al., 2013; Tanzi, 1998; Treisman, 2000).

One aspect that needs to be studied about village governance in the era of village autonomy is the human resource capacity of village government in managing village government (Riskasari, 2016) according to goals and demands (Undang-Undang Nomor 6 Tahun 2014 Tentang Desa, 2014). The capacity of the village government is considered not yet able to carry out the authority it has by the village law. The weak capacity of the village government has an impact on the failure to implement village laws, leading to poor village development (Eko et al., 2014; Riskasari \& Tahir, 2019; Sulila, 2020). The demands of the 


\section{Jurnal Administrare: Jurnal Pemikiran Ilmiah dan Pendidikan Administrasi Perkantoran \\ Volume 8 Issue 1, January-June 2021. Pages 37-42}

village government to implement village autonomy as broadly as possible (Eko et al., 2014) were answered by enactment (Undang-Undang Nomor 6 Tahun 2014 Tentang Desa, 2014). Through the Village Law, the existence of the village government as part of the government structure is increasingly recognized as an independent village government and has the right to manage the potential of each village government.

Because of this, most village governments in Indonesia have welcomed this implementation (Undang-Undang Nomor 6 Tahun 2014 Tentang Desa, 2014). This is because the law places the village government as the subject of village development. The village government has broad autonomy, and the village government has the authority to regulate village governance according to their respective potential. One important aspect in the implementation of village funds is the distribution of village funds from the Government Budget State Expenditure to the village government (Gunartin, 2020; Ibrahim, 2019; Sulila, 2020). Although village funds are the right of the village government, in terms of its implementation, village fund distribution still involves the roles and functions of local governments by their authority (Wibawa. S, Pratama, A.B, 2019 \& Sayidah, 2019).

To realize the principles of transparency and accountability and ensure the achievement of the use of village funds, the process of distributing village funds requires several criteria that must be met first, both by the village government as users of village funds and by city districts. Related provisions regarding the distribution of village funds are regulated in the Minister of Finance regulation no. 50 / PMK.07 / 2017 concerning the management of transfers to regions and village funds, as amended by the Minister of Finance Regulation No.112 / PMK.07 / 201 In line with the development targets for rural areas in the 2015-2019 RPJM, the use of village funds needs to be directed to support the alleviation of backward villages for the sake of realizing village independence. The use of Village Funds is the right of the Village government by the authority and priority needs of the local village community while maintaining the principle of justice. (Sani, K. R \& Mursak, 2012)

Refer to the analysis of the concept of capacity in the context of village government entities in the Indonesian state administration system and a review of the literature on the concept of capacity in public organizations. Contextually, the village government is an administrative entity that stands in the areas of political and managerial policy. The juridical fact is that the village has an organ that is compatible with the regional government, namely the executive is the village head, who is supported by the bureaucracy, namely the village apparatus, and the legislature is the Village Consultative Body. From a content perspective, capacity can be understood in 3 realms of analysis, namely capacity as a resource, capacity as capability, and capacity as performance. However, in this study, especially for the internal organization of the management area of the utilization of village funds, the focus of this research is focused on capacity as a resource, namely human resources, finance, and organizational infrastructure.

\section{METHOD}

To obtain accurate data in this research, the method used is qualitative research methods, qualitative research is considered suitable for conducting research related to the capacity of village government in managing village funds where qualitative research sees firsthand the problems that occur and so in the form of administrative accountability reports and also the 
results of the work program or output or can be seen from the impact on the level of community welfare. The data collection techniques used in this study are interviews, observation, and documentation.

\section{RESULT AND DISCUSSION}

The implementation of development in the Pulau Sembilan District, Sinjai district with the support of village funds as can be seen in the following table:

Table 1.

Total Realized Village Fund Budget in Pulau Sembilan District in 2019

\begin{tabular}{llcc}
\hline Number & Village & Budget & Realization \\
\hline 1 & Harapan Island & Rp. 1.497.257.000 & Rp. 1.453.181.300 \\
2 & Persatuan Island & Rp. 994.064.000 & Rp. 974.758.430 \\
3 & Buhung Pitue Island & Rp. 1.244.539.630 & Rp. 1.241.105.270 \\
4 & Padaelo Island & Rp. 1.204.009.851 & Rp. 1.196.707.898 \\
\hline
\end{tabular}

Source: Village Community Empowerment Service of Sinjai Regency (realization report)

Peraturan Pemerintah Nomor 8 Tahun 2016 is the second change over (Peraturan Pemerintah Nomor 60 Tahun 2014 Tentang Dana Desa, 2014) which is sourced from the budget for state expenditure, the village fund is assistance from the government which comes from the state budget for the village to finance governance, implementation of development, community development, community empowerment. Also, the objectives of village funds include: improving public services, reducing poverty, advancing the community's economy, overcoming development gaps between villages, and strengthening rural communities as the subject of development.

\section{Human Resources Management}

The success and failure of an organization are largely determined by the management of human resources, therefore human resources are needed in a government organization as the technical implementer of administrative activities.

Human resource management can be seen from various aspects, such as community involvement, skills, and expertise development, providing opportunities for self-actualization, providing employment, and others.

Based on the data obtained from research locations related to human resource management, among the four villages in the Sembilan island sub-district, only two villages run the village government system and involve the community both in terms of development planning and in the implementation of development. Like community empowerment, and the two other villages in running the government do not involve the community in the development planning process or the implementation of development. Administrative personnel used to support the government system, the success of an organization is not carried out by one person alone, but it requires the involvement of many people and is needed the ability to manage and manage human resources.

\section{Financial}

In the implementation of development in the Sembilan island sub-district, especially the use of village funds, of course, it cannot be separated from the bargaining of financing activities 
or mapping of work programs that can be used as village development programs that can be financed by village funds. Of the four villages in the Sembilan island sub-district in the management and utilization of village funds, especially financing, refers to the existing budget ceiling in each village and still observes applicable rules such as evidence of financing evidence for reporting and accountability, especially routine financing as support. implementing administrative services, as well as other forms of financing such as wages or salaries for administrative staff or heads of hamlets and village consultative bodies.

\section{Infrastructure Development}

The development of village infrastructure is a matter of concern for the government to meet community needs, especially the construction of road and bridge infrastructure. However, it can be seen from the point of view of needs that sometimes it is not directly proportional to the needs of the geographical conditions. The need for road and bridge infrastructure is not general depending on the conditions of the area, as the existing conditions in the Pulau Sembilan sub-district which has a limited area and is surrounded by the sea are certainly not a priority program from year to year. Of the four villages in the Sembilan island sub-district every year there has been infrastructure development from 2015 to 2019 with limited regional conditions, of course, the potential for needs that do not have a positive impact on the welfare of the village community or even the quality of development is not good. In the management and utilization of village funds in two villages, Padaelo and Buhungpitue, there is no transparency in the implementation and utilization of village funds as evidenced by some information that the researchers got from the community and the absence of a construction project board that is installed in infrastructure development activities, as well as types of development programs funded by village funds as well as other villages that generally install and display large banners/billboards that are installed in front of the village office.

\section{Discussion}

The results of this study found a weak function of the village consultative body. The village consultative body is a representative from the village area (hamlet) of at least five people and a maximum of nine people who can represent the community in village deliberations, or function to accommodate the aspirations of the community and draft a village regulation. The results of this study reveal the weakness of the appropriate function of the village consultative body (Undang-Undang Nomor 6 Tahun 2014 Tentang Desa, 2014) article 61 point a. "Supervise and request information about the implementation of Village Government to the Village Government". The village consultative body is not subordinate to the village head but is part of the village administration which synergizes with each other in running the government at the village level. Members of the village consultative body must pay attention to and enforce existing regulations at the village level and higher regulations and give consideration to the village head in implementing village governance.

In the village government governance system, it is expected that tighter supervision is needed about the management of village funds from the provincial and district city governments which are supported by strong regulations without any interference to the village but to realize the development and empowerment of village communities that are right on target. There is a need to increase the capacity of village consultative bodies in implementing village government so that they can synergize between BPD and the head of the village in carrying out the village 
government system both in terms of community services and in terms of infrastructure development.

Lack of transparency in the management of village funds. The mistake that the village head has in understanding the law on village autonomy, the village Pada elo sub-district of Pulau Sembilan thinks that the position of the village head is the highest in the village area and has the right to regulate his government system and should not be regulated by anyone, the perception of this village head is certainly not wrong but it should be noted that by article 19 (Undang-Undang Nomor 6 Tahun 2014 Tentang Desa, 2014) especially in points c and d related to authority, that is the authority of the village head is the authority assigned to the provincial government or district city government or other authority imposed from the provincial government or city district government by the provisions and regulations in force. Also, in carrying out the duties of the village head according to (Undang-Undang Nomor 6 Tahun 2014 Tentang Desa, 2014) Article 26 paragraph 4 point $f$ the village head "implements the principles of village governance that is accountable, transparent, professional, effective and efficient, clean, and free from collusion, corruption, and nepotism;" in accordance with the explanation in this paragraph, of course a village head must understand that even though the authority of the village head in managing village funds must pay attention to transparency and accountability as described in article 26 paragraph 4 (Undang-Undang Nomor 6 Tahun 2014 Tentang Desa, 2014) villages have genuine autonomy rights based on customary law, can determine the structure of government, regulate and manage their households and have assets and assets. (Undang-Undang Nomor 6 Tahun 2014 Tentang Desa, 2014) is an autonomous region given rights related to financial management and allocation of village funds, the election of village heads, and village development. However, it must be remembered that behind rights there must be obligations and if there is authority there must be responsibility and there is no freedom without limitations.

\section{CONCLUSION}

The results showed that the capacity of the village government in managing the village fund budget in Pulau Sembilan District, Sinjai Regency shows that human resource management is not carried out optimally, from the financial aspect it is carried out according to applicable procedures, while in terms of infrastructure development it is found that the quality of development is in a bad category. Thus, there is a need for tighter supervision related to the management of village funds from the provincial and district city governments which are supported by strong regulations without any interference to the village but to realize the development and empowerment of village communities that are right on target

\section{REFERENCES}

Eko, S., Khasanah, T. I., Widuri, D., Handayani, N., Qomariyah, P., Aksa, S., \& Kurniawan, B. (2014). Desa Membangun Indonesia.

Gunartin, G. (2020). Analysis of the Village Head's Leadership Style in Cidokom Gunung Sindur Village, Bogor District. Jurnal Ilmiah Ilmu Administrasi Publik, 10(1), 75-84.

Ibrahim, I. (2019). Analysis of Management of Village Fund Allocation (ADD) in Pohuwato Regency. Jurnal Ad'ministrare, 6(1), 25-34.

Kiki Rasamal Sani, M. (2012). Penguatan Kapasitas Pemerintah Desa dalam Pengelolaan Pemerintahan Desa di Kabupaten Sinjai. Administrasi'ta, 9(2), 101-114. 
Mauro, P. (1998). Corruption and the composition of government expenditure. Journal of Public Economics. https://doi.org/10.1016/S0047-2727(98)00025-5

Peraturan Pemerintah Nomor 60 Tahun 2014 Tentang Dana Desa, (2014).

Persson, A., Rothstein, B., \& Teorell, J. (2013). Why anticorruption reforms fail-systemic corruption as a collective action problem. Governance. https://doi.org/10.1111/j.14680491.2012.01604.X

Prasodjo, T. (2017). Tata Kelola Administrasi dan Pengembangan Desa Inovatif Berbasis Riset. Jurnal Ad'ministrare: Jurnal Pemikiran Ilmiah Dan Pendidikan Administrasi Perkantoran, 4(1), 35-40.

Rakib, M., \& Syam, A. (2016). Pemberdayaan Masyarakat Melalui Program Life Skills Berbasis Potensi Lokal Untuk Meningkatkan Produktivitas Keluarga Di Desa Lero Kecamatan Suppa Kabupaten Pinrang. Jurnal Ilmiah Ilmu Administrasi Publik: Jurnal Pemikiran Dan Penelitian Administrasi Publik, 6(1), 96-108.

Riskasari, R. (2016). Akuntabilitas Pengelolaan Alokasi Dana Desa di Desa Bongki Lengkese Kecamatan Sinjai Timur Kabupaten Sinjai. Jurnal Office, 2(2), 125-132.

Riskasari, R., \& Tahir, N. (2019). Collaboration of Development Actors in Realizing Mandiri Villages in Bongki Lengkese Village, East Sinjai District, Sinjai District. Jurnal Ilmiah Ilmu Administrasi Publik, 8(2), 121-126.

Samodra Wibawa, Arif Budy Pratama, F. \& C. W. (2019). Menata Desa: Bunga Rampai Pemikiran (Issue July). Penerbit K-Media.

Sayidah, N. (2019). Akuntabilitas Pemerintah Desa dalam Pengelolaan Dana Desa di Desa Penompo. Analisa Akuntansi Dan Perpajakan, 3(1), 117-124.

Sulila, I. (2020). An Analysis of the Effectiveness of Allocation of Village Fund Policy Implementation and Its Determining Factors in Gorontalo Regency. Jurnal Ilmiah Ilmu Administrasi Publik, 9(2), 191-202.

Tanzi, V. (1998). Corruption Around the World: Causes, Consequences, Scope, and Cures. IMF Staff Papers. https://doi.org/10.2307/3867585

Treisman, D. (2000). The causes of corruption: A cross-national study. Journal of Public Economics. https://doi.org/10.1016/S0047-2727(99)00092-4

Undang-Undang Nomor 6 tahun 2014 Tentang Desa, (2014).

Wijaya, C., \& Sari, V. D. P. (2020). Encouraging Collaborative Governance in Badan Usaha Milik Desa (BUM Desa) Management in Indonesia. Jurnal Ilmiah Ilmu Administrasi Publik, 9(2), 225-236.

Zulkifli, Z., Suasa, S., Mukarramah, M., Daswati, D., \& Samad, M. A. (2018). Village Funds Supervision by the Village Consultative Body (BPD) in Batumatoru Village, Lariang District, Pasangkayu Regency. PINISI Discretion Review, 1(2), 109-112. 